DOI https://doi.org/10.30525/978-9934-26-004-9-31

\title{
СИМВОЛІЗМ «ПРОБЛЕМИ ХЛІБА» НА ПРИКЛАДІ ЦИКЛУ В. ПІДМОГИЛЬНОГО «ГОЛОД»
}

\author{
Сірікова Л. І. \\ учитель мистецтва вищої кваліфікаиійної категорї, \\ вчитель-методист \\ Школи I-ІІІ ступенів № 25 Шевченківського району міста Києва \\ м. Київ, Украӥна
}

Основою «проблеми хліба» $є$ феномен смерті та вибору. Досвід показує, що критична ситуація зустрічі зі смертю може каталізувати смисложиттєвий пошук особи, а може й засвідчити ії остаточне духовне банкрутство.

Новелла В. Підмогильного «Собака» відкриває групу творів про голод в Україні 20-х років XX століття. Це, звичайно, умовне і спрощене визначення тематики цих творів. Скоріш, голод виступає каталізатором рухів душі людської на межі життя і смерті, бо перед смертю ніхто не в змозі приховати все те потаємне, що гніздиться в самих далеких закутках серця. Всі три твори ми ставимо в один ряд відповідно до сюжетної лінії, до динаміки розгортання драматургії, до зростання напруження, що $\epsilon$ символічним.

Можна провести багато паралелей між цим циклом творів та творами інших видів мистецтва. Одна з таких асоціацій - музична. Відомо, що в три частинній музичній формі існує певний, виважений віками, розподіл ходу сюжетної лінії, а саме: I частина - презентація головних героїв, II частина - їх зіткнення, або співіснування, хоча теж контрастне, III частина - фінал. Стосовно творів В. Підмогильного про голод, цілком доречно застосувати цю систему. В новелі «Собака» автор презентує головних героїв - Людину і ворожий до неї світ в образі Голоду, який тяжким каменем ліг на спини людей, позгинав їх до землі, поставив на коліна. Автор дає старт розвиткові ідеї про «людину на перехресті». Відомо, що будь-яке явище зароджується, проходить всі етапи розвитку, витримує кульмінацію, після якої перетворюється на свою протилежність. Людина ж перетворюється у спотворену подібність до самої себе, якщо в неї нема сталевого духу моралі. Молодий студент побудував «високу й грубу стіну з книжок..., що раз менше бачив він життя» Він жив у своїй фортеці, як хотів, і раптом опинився між «Кантом 
i борщем, Ніцше і ковбасою» [1]. Цікаво, що автор в цю фразу, яка вже й так містить дві протилежності, ввів ще й третю, більш загальну. Справа в тому, що Ніцше не визнавав Канта, вважав його філософію не тільки хибною, а й небезпечною для людини: «І чому це не відчули, який ворожий життю Кантів категоричний імператив... Це ж бо найкоротший шлях до decadence'у, ба навіть ідіотизму... Отже, Кант - ідіот... I така людина була сучасником Гете! Лиховісний павук уважався німецьким філософом...» [2]. Тімегрей навіть на вислів Декарта «Я мислю, отже, існую», відповідає, «та ось приходить голод й спиняється у шлунку, як знак запитання. I ми без вагання даємо відповідь, раптом бачимо, що ми ссавці» [1]. В. Підмогильний міг би повернути сюжетну лінію в інший напрямок, але все жповертає йому його «я» за допомогою собаки, яка випадково потрапляє на очі. Собака «вказує» герою можливий вихід із скрутного становища, чим, ймовірно, врятовує його від перетворення.

В умовному розподілі трьох творів В. Підмогильного оповідання «Проблема хліба» стоїть на другій, центральній позиції, і як друга частина в музичній формі - та межа, на якій у боротьбі зустрічаються головні герої: саме тут і зараз відбувається вбивство людини людиною заради їжі, ось вона - кульмінація, - саме в цьому творі і відбувається спотворення людини. У творі «Проблема хліба» $є$ ремарки автора стосовно того, коли відбувалися події. Знову залізна логіка В. Підмогильного. Початок твору - висвітлення проблеми - нема позначки часу, тому що для виникнення будь-якої проблема час не має значення. Рішення героя стати спекулянтом відбувається о першій годині дня (теж десь посередині). Все - герой став на згубний шлях, і ніщо не може повернути його назад, приходить ніч, якій герой виголошує славу!

Даючи, на відміну від першого твору, головному герою у «спасителі» літню, негарну перекупку, у якої він сито набиває шлунок «масними пиріжечками», автор починає поступовий перехід проблеми від особистої до загальної. I знову ж таки паралель зі світу музики. Геніальний композитор Модест Петрович Мусоргський створив безсмертний цикл під символічною назвою «Песни и пляски смерти». Там сюжетна лінія проходить шлях від окремого до загального. Перша частина циклу - «Колискова» - рамки однієї хати - один герой - дитина; друга частина - «Серенада» - це вже межі цілого будинку, території, навкруги його - два героя - головний - доросла людина; далі «Трепак»- завуальований герой, сп'янілий мужичок, який потрапляє в дику заметіль /герой один, але вже не при здоровому розумі, тобто за межею/; і нарешті, «Полководець» - героїв багато, але вони - загиблі на 
полі битви. Причому, не має значення на якому боці вони воювали, для смерті всі рівні.

В. Підмогильний своїм геніальним талантом вибудовує подвійну лінію від окремого до загального. Перша проходить між трьома творами про голод: «Собака» - один герой, «Проблема хліба» - два герої. хоч головний начебто один, «Син» - багато героїв. I так, як у Мусоргського, друга межа перетворення проходить у середині циклу, так і у Валер'яна Петровича воно відбувається у творі «Проблема хліба». Письменник вмістив це складне психологічне явище лише у декілька речень, але зробив це так яскраво, глибоко і влучно. Ось коли було закладена смерть матері 3 твору «Син»: життя героя не співпадає з загальною трагедією людства. А чого ж? Він вже над людиною, він як сонце, котрому вклоняються. Герой твору «Син» попадає в зовсім іншу ситуацію, і автор всі хибні, спотворені риси передає не Грицьку, а його рідній сестрі Марійці. Не Васюренко вбиває матір, а безіменний студент, який дозволив собі зрадити, вбити саму природу, яка його народила, стати над нею, увібрати в себе функцію смерті. 3 того самого моменту, коли Безіменний «добув із кишені приховану на собаку каменюку та шерехнув нею діда по голові... на землі відбулося ще одне згубство». [3] В »Проблемі хліба» на світ 3'являється ще одна, але мабуть, найжахливіша паралель. У світі фентезі /який до речі $є$ тільки на самий малий відсоток штучно створеним/ існує легенда про Безіменних, які отримавши свободу, «забирають» душу свого визволителя, спотворюють iii і починають полювання на інші. Щоб знищити Безіменного необхідно сказати його ім'я. Відповідь може знайти тільки сама людина, якщо не схоче своєї моральної загибелі. Це дуже важко, бо ім'я потвори - це ім'я його носія, тобто самої людини. Ї не фізичного втілення, а духовного, яке має дві сторони - світлу і темну. Так ось Безіменний - це темна сторона людини. Хоча за законами діалектики і він, безіменний студент, який сприймає «масні пиріжки» як щасливе послання долі, інколи, споглядаючи самого себе збоку, над плином реального життя, таки усвідомлює, що існує «холодною хризантемою на угноєній землі», відчуває, як «сум кладе на обличчя м'які пучки». За ситість фізичну доводиться розплачуватися втратою духовності - закон природи діє невідворотно.

Дуже виразна і яскрава мова творів, яка породжує асоціативну паралель із символікою живопису. Досить прочитати тільки початок новели «Собака», як одразу потрапляєш у ту атмосферу: «місто поменшало», «вони /люди/ позгинали стан, мов би несли на спині велику ношу». I гостре, як ніж, слово «порожнеча» розрізає думку і душу, і весь 
світ навколо. Згадаймо, «безкрая палюча жовтизна різала очі...» («Син»). А чого варте поєднання в творах, особливо в «Сині», двох кольорів жовтого і червоного - «жовтий мертвий степ», «весь світ брався в його очах червоними, страшними колами...». У живописних символах поєднання жовтого i червоного кольорів символізує пекло, жах, божевілля. Саме туди потрапляє Васюренко ще за життя, бо в хаті «сморід», «серце затіпалося млосно, стискуючись у безнадії й заздрості», «навіть коники не сюрчали, не літала мушва»- самотність і порожнеча. Картина пекла, змальована художником слова.

\title{
Література:
}

1. Мельник В.О. Валер'ян Підмогильний. - К.: «Знання», 1991 - 48 с.

2. Ніцше Фрідріх. Так казав Заратустра. - К.: «Основи», «Дніпро», $1993-414$ c.

3. Українське слово. Хрестоматія української літератури та літературної критики ХХ ст., кн. 2. - К.: «Рось», 1994 - 718 с.

DOI https://doi.org/10.30525/978-9934-26-004-9-32

\section{ОСНОВНІ ФОРМИ ТА МЕТОДИ ІДЕОЛОГІЧНОГО КОНТРОЛЮ ВЛАДИ В ГАЛУЗІ КУЛЬТУРИ В УКРАЇНІ (40-50-ТІ РОКИ ХХ СТ.)}

\author{
Сірук Н. М. \\ кандидат історичних наук, \\ дочент кафедри документознавства та інформаційної діяльності \\ Редчук Р. О. \\ кандидат педагогічних наук, \\ доиент кафедри документознавства та інформаиійної діяльності \\ Приватного вищого навчального закладу \\ «Академія рекреаційних технологій та права» \\ м. Луцьк, Україна
}

В сучасних умовах, в період незалежної Української держави, особливого значення набуває відродження національної історичної пам'яті. У зв'язку з цим значний науковий i пізнавальний інтерес становить дослідження духовного життя в Україні другої половини 40-х - початку 50-х років XX ст., зокрема ідеологічного контролю 